\title{
The Effects Of Female Size On Fecundity In A Large Marine Gastropod Rapana Venosa (Muricidae)
}

Juliana M. Harding

Virginia Institute of Marine Science

Roger L. Mann

Virginia Institute of Marine Science

Catherine W. Kilduff

Virginia Institute of Marine Science

Follow this and additional works at: https://scholarworks.wm.edu/vimsarticles

Part of the Marine Biology Commons

\section{Recommended Citation}

Harding, Juliana M.; Mann, Roger L.; and Kilduff, Catherine W., "The Effects Of Female Size On Fecundity In A Large Marine Gastropod Rapana Venosa (Muricidae)" (2007). VIMS Articles. 443.

https://scholarworks.wm.edu/vimsarticles/443 


\title{
THE EFFECTS OF FEMALE SIZE ON FECUNDITY IN A LARGE MARINE GASTROPOD RAPANA VENOSA (MURICIDAE)
}

\author{
JULIANA M. HARDING, ${ }^{1 *}$ ROGER MANN ${ }^{1}$ AND CATHERINE WARE KILDUFF ${ }^{1,2}$ \\ ${ }^{1}$ Department of Fisheries Science Virginia Institute of Marine Science P.O. Box 1346 Gloucester Point, \\ Virginia 23062; ${ }^{2}$ University of Virginia School of Law, 580 Massie Road Charlottesville, \\ Virginia 22903 (present address)
}

\begin{abstract}
The life history strategy of the veined rapa whelk Rapana venosa, a temperate marine gastropod, includes generation times of $1 \mathrm{y}$, individual longevity of $>10 \mathrm{y}$, annual production of egg cases, and an adult size range of 40 to $>160 \mathrm{~mm}$ shell length (SL). This life history combined with the animal's generalist ecological preferences and broad physiological tolerances makes rapa whelks well suited for ecological success along a gradient of habitat and community types. Ballast water transport of veliger larvae across traditional zoogeographic boundaries has resulted in the establishment of invasive rapa whelk populations in Chesapeake Bay, USA, as well as European habitats. Although the need for a quantitative understanding of rapa whelk reproductive biology in terms of annual embryo production or fecundity is acknowledged as a necessary step in assessing the biological and ecological consequences of such an invasion, rapa whelk fecundity in relation to size for the entire adult size range (40->160 mm SL) has not previously been quantified. The relationships between rapa whelk female size and egg case height, number of embryos egg case ${ }^{-1}$, number of egg cases produced female whelk $\mathrm{k}^{-1} \mathrm{yr}^{-1}$ and fecundity, and the number of embryos female $\mathrm{yr}^{-1}$, are described for a size range of individuals from Chesapeake Bay. In 2001 and 2003, egg laying began in mid to late May at water temperatures of approximately $18^{\circ} \mathrm{C}$ and salinities $14-20 \mathrm{ppt}$ and continued for $11-12 \mathrm{wk}$. The smallest rapa whelk observed (45 mm SL, $5.8 \mathrm{~g}$ wet tissue weight) laid egg cases with heights of approximately $7 \mathrm{~mm}$. The largest whelk (163 $\mathrm{mm} \mathrm{SL}$, $220 \mathrm{~g}$ ) laid egg cases with heights $30-33 \mathrm{~mm}$. The number of embryos observed in egg cases produced by Chesapeake Bay rapa whelks ranged from 123 embryos in a $7.4 \mathrm{~mm}$ high egg case to 3,673 embryos in a $33.5 \mathrm{~mm}$ high egg case. Rapa whelk fecundity (number of embryos female $\mathrm{yr}^{-1}$ ) increased with female size. Egg case production was observed in rapa whelks that had hatched from egg cases and recruited within the previous year ( $<1 \mathrm{y}$ old). Small $(<80 \mathrm{~mm} \mathrm{SL},<28 \mathrm{~g}$ wet tissue weight $)$ rapa whelks have relatively lower annual fecundities $\left(1 \times 10^{5}\right.$ embryos female $\left.\mathrm{yr}^{-1}\right)$ than large $(>80 \mathrm{~mm} \mathrm{SL},>28 \mathrm{~g}$ wet tissue weight $)$ rapa whelks that may produce between $1 \times 10^{6}$ and $4 \times 10^{6}$ embryos female $^{-1} \mathrm{yr}^{-1}$. Estimates of rapa whelk fecundity, even for small rapa whelks, are at least an order of magnitude greater than similar estimates for native United States Atlantic coast gastropods.
\end{abstract}

KEY WORDS: veined rapa whelks, Rapana venosa, fecundity, egg case, embryo, parental size, muricid, allometry

\section{INTRODUCTION}

Predatory marine gastropods display a range of life history strategies that balance the requirements of maintenance, growth, and reproduction (e.g., Spight et al. 1974). Fitness is typically described in terms of the number of offspring, and reproductive strategies are designed to maximize parental contribution to next generation. In theory, reproductive strategies are designed to maximize reproductive success of a species. Most large marine gastropods delay reproduction so that energy early in life may be directed towards growth and attainment of size refuge from predation (Spight et al. 1974).

Many marine gastropods package fertilized embryos into individual egg cases or capsules that are deposited as masses or groups cemented onto hard substrate (Pechenik 1986, D'Asaro 1991). Female size has been positively related to fecundity (embryos female ${ }^{-1}$ year $^{-1}$ ) both in gastropod species that produce a single egg mass or clutch year ${ }^{-1}$ (e.g., Ceratostoma foliatum, Spight et al. 1974; Thais lamellosa, Spight \& Emlen 1976) as well as gastropods that produce multiple egg masses per breeding season or year (e.g., Eupleura caudata: MacKenzie 1961; Buccinum isaotakii: Ilano et al. 2004). The periodicity of egg capsule deposition within a breeding season increases with available food supply (Thais emarginata, Spight \& Emlen 1976). Many of the muricids for which fecundity:size relationships

*Corresponding author. E-mail: jharding@vims.edu have been described, reach relatively small adult sizes (20$30 \mathrm{~mm} \mathrm{SL}$, the maximum dimension from the spire to the end of the siphonal canal; e.g., MacKenzie 1961, Franz 1971, Spight et al. 1974), although these relationships in somewhat larger species (maximum size $70-80 \mathrm{~mm} \mathrm{SL}$ ) have also been examined (e.g., Ceratostoma foliatum; Spight et al. 1974, Stramonita haemastoma; Burkenroad 1931, Butler 1954, D'Asaro 1966). Fecundity:size relationships within a single species including representative adult individuals that span a size range of shell lengths from 40 to $>160 \mathrm{~mm}$ have not been previously described.

The veined rapa whelk (Rapana venosa) is a marine gastropod that reaches large adult sizes, but is reproductively active early in life. Rapa whelks are long lived (in excess of $15 \mathrm{y}$ ) and may reach adult sizes greater than $160 \mathrm{~mm}$ shell length. These whelks are reproductively capable within 1 y postrecruitment at sizes of 35-50 mm SL (Harding, unpublished data) and annually produce multiple clutches or groups of egg cases that release planktonic larvae after an incubation period of 14-28 d (Chung et al. 1993, Harding 2006). This dual life history strategy combined with the animal's generalist food and habitat preferences and wide physiological tolerances (Mann \& Harding 2000, 2003) make rapa whelks well suited for ecological success along a gradient of habitat and community types. Although rapa whelks are native to marine habitats off Japan and the Korean peninsula, they were introduced to the Black Sea immediately after World War II and have since spread throughout the Mediterranean, Aegean, and Adriatic seas 
(Mann et al. 2004). In the past decade, rapa whelk populations have been reported from the Chesapeake Bay (1998; Harding \& Mann 1999, 2005), the Brittany coast of France (1999, Dr. Philippe Goulletquer, IFREMER, personal communication), the Rio del Plata, Uruguay and Argentina (2000; Pastorino et al. 2000, F. Scarabino, National Museum of Natural History and National Institute of Fisheries, Uruguay, personal communication), and the Netherlands (2005; Vink et al. 2005).

Historically, large long-lived gastropods were not among the primary candidate fauna for anthropogenic transport to other habitats (Carlton 1999). Geographic range expansion by these benthic infauna relied on slow progression of individuals crawling into new areas, transport with aquaculture species or as part of hull fouling or sea chest communities, or dispersal of planktonic larvae by water currents within the established range of ecological tolerances. Reliance on ballast water by commercial shipping offers a rapid vector for dispersal of large predatory gastropods that have planktonic larvae across natural zoogeographic boundaries. In the absence of natural controls, the consequences of these introductions may be ecologically traumatic. For example, rapa whelks are credited with extermination of commercial oyster beds on the Gaudauta oyster bank in the Black Sea within a decade of their introduction (Drapkin 1963).

Given the recent documented introductions, a quantitative understanding of rapa whelk reproductive biology is a necessary step in assessing the biological and ecological consequences of an invasion (Sakai et al. 2001). The relationships between rapa whelk female size and egg case height, number of embryos egg case ${ }^{-1}$, number of egg cases produced female whelk ${ }^{-1} \mathrm{yr}^{-1}$ and fecundity, and the number of embryos female ${ }^{-1} \mathrm{yr}^{-1}$ were quantified and are described here for a size range of rapa whelks from Chesapeake Bay.

\section{MATERIALS AND METHODS}

\section{Whelk Sources}

A size range ( $73-163 \mathrm{~mm} \mathrm{SL})$ of wild female rapa whelks $(n=$ 14 females) was collected during April to May 2001 from Chesapeake Bay, USA. These females were isolated in flow through chambers at ambient conditions to serve as broodstock for this study and that of Ware (2002). Containers were maintained in floats deployed along the 1-m depth contour in the York River, Virginia near Gloucester Point, Virginia, from May through August 2001. Excess food (hard clams, Mercenaria mercenaria) was available in each chamber. Each female whelk was measured (SL, mm) at the beginning (May 2001) and end (August 2001) of the study. Whelks were isolated prior to the onset of egg case deposition and maintained in chambers for two weeks after the last observed egg case deposition by that individual. Thus the study spanned the entire duration of the 2001 egg-laying season. At the termination of the study, whelks were sacrificed to obtain wet tissue wet weight $(\mathrm{g})$ for each female.

In 2003, eight groups of rapa whelks with 2 females per group ( $n=16$ females) cultured at the Virginia Institute of Marine Science (VIMS) ranging from 45-83 mm SL were selected for enumeration of embryos per egg cases. This size range was selected to provide data for rapa whelks less than
$70-80 \mathrm{~mm}$ SL (the size of the smallest wild caught whelks available). Cultured rapa whelks were maintained in flow through systems at ambient York River, VA water temperatures $\left(4^{\circ} \mathrm{C}\right.$ to $\left.28^{\circ} \mathrm{C}\right)$ and salinities $(11-18 \mathrm{ppt})$. They were fed local bivalve prey (e.g., hard clams, Eastern oysters Crassostrea virginica, softshell clams; Mya arenaria, and blue mussels Mytilus edulis) in excess. Cultured whelks were held in groups of three to six individuals. The average shell length for the entire group was calculated from weekly measurements of all individuals within the group and used to describe female size.

York River water temperature $\left({ }^{\circ} \mathrm{C}\right)$ and salinity (ppt) were measured daily for the duration of the egg-laying season in 2001 and 2003.

A rapa whelk shell length-tissue wet weight relationship for the size range of animals in these experiments was calculated using shell length $(\mathrm{mm})$ and wet tissue weight $(\mathrm{g})$ for 42 cultured individuals (SL 18-85 mm) combined with the SL and wet tissue weight measurements from the 14 wild whelks.

\section{Experimental Protocol}

\section{Egg Mass and Egg Case Collection}

Egg masses were collected twice a week from wild whelks (May through August 2001) and cultured whelks (June through August 2003). An egg mass is defined as an isolated group of egg cases attached to the side of the holding container. At the time of collection, the number of individual egg cases with the egg mass was counted. Immediately after collection, egg masses were placed in 1-L filtered seawater and taken to the laboratory for enumeration of embryos. In the laboratory, each egg mass was placed on a grid with $1 \mathrm{~mm}$ squares. Three to five egg cases were randomly selected from each egg mass and were removed from the egg mass by carefully excising the egg cases from the egg mass' mucoid basal plate. After removal from the egg mass, egg cases were immediately placed into individual petri dishes and covered with filtered seawater at ambient water temperature and salinity. Care was taken during both egg mass collection and removal of egg cases from an egg mass not to puncture or damage individual egg cases.

\section{Enumeration of Eggs Per Case}

Egg case height (the maximum distance from basal plate to apical pore, $\mathrm{mm}$ ) was measured to the nearest $\mathrm{mm}$ from digital images of each egg case with a computer based image analysis system (wild whelks) or with calipers (cultured whelks). Individual egg cases were dissected under a dissecting microscope by removing the basal end of the egg case and making a vertical cut up the wall of the egg case, if necessary, to gently release the embryos into the petri dish.

All embryos from individual egg cases $<30 \mathrm{~mm}$ high were counted a minimum of three times under a dissecting microscope. Counting error was estimated by comparing the three different counts for the embryos within the same egg case. Counting error was kept to less than $1 \%$ for each egg case.

The number of embryos in egg cases taller than $30 \mathrm{~mm}$ was estimated by dilution (Ware 2002): embryos from a single egg case were rinsed into 7 or $10 \mathrm{~mL}$ of filtered seawater and three successive 1-mL aliquots were removed for enumeration after gentle mixing. Only egg cases where the coefficient of variation 
(Zar 1996) within each egg case sample was $<0.2$ were considered for this study to reduce within egg case variation because of dilution error (per Van Guelpen et al. 1982; Mohlenberg 1987). Counting error using the dilution method was less than $2 \%$ for each egg case.

\section{Data Analyses}

Significance levels for all tests were established at $P=0.05$ a priori. When necessary, Fisher posthoc multiple comparison test was used.

\section{Female Shell Length Over Time}

Measurements of individual wild whelks (SL, mm) recorded in May 2001 at the beginning of egg laying season were compared with individual shell lengths measured at the end of egg laying season on August 28, 2001 with an ANOVA using month of measurement as a factor and individual shell length as a response. Measurements of cultured female shell lengths ( $\mathrm{mm})$ before the beginning of egg laying season (May 2003) and immediately after the end of egg laying season (August 25, 2003) were also compared using month of measurement as a factor and individual shell length as a response. In both cases, data satisfied assumptions of homogeneity of variance and normality without transformation.

\section{Female Tissue Wet Weight in Relation to Female Shell Length}

Rapa whelk shell lengths ( $\mathrm{mm}$ ) from the 14 wild whelks and 42 cultured whelks with SL $<80$ were plotted in relation to total wet tissue weight ( $\mathrm{g}$ ) to establish a shell length-wet tissue weight relationship for the size range of whelks in these experiments. Wet tissue weight $(\mathrm{g})$ is a more representative metric for female size at a given moment than shell length ( $\mathrm{mm})$ because of seasonal fluctuations in female body weight. Once laid down, the shell does not shrink or change seasonally in relation to the body weight of its occupant. The relationship between shell length and wet tissue weight (above) was used to estimate wet tissue weight $(\mathrm{g}$ ) for the cultured whelks that were not sacrificed at the end of the experiment.

\section{Number of Embryos Per Egg Case in Relation to Egg Case Height}

The average number of embryos per egg case $( \pm \mathrm{SE}$ of the mean) was plotted in relation to egg case height $(\mathrm{mm})$.

\section{Egg Case Height in Relation to Female Wet Tissue Weight}

Egg case height $(\mathrm{mm})$ was plotted in relation to female wet tissue weight (g). Individual ANOVAs were used to test for variation in egg case height with week of the egg-laying season for female whelks. Data satisfied assumptions of homogeneity and normality without transformation.

\section{Number of Embryos Per Egg Case in Relation to Female Wet Tissue Weight}

The number of embryos per egg case was plotted in relation to female wet tissue weight ( $\mathrm{g}$ ). Individual ANOVAs were used to test for variation in number of embryos per egg case with week of the egg-laying season for females. Data satisfied assumptions of homogeneity and normality without transformation.
Number of Egg Cases Laid by an Individual During One Year (Egg Laying Season) in Relation to Female Wet Tissue Weight

The total number of egg cases laid by one female whelk in one year was plotted in relation to the female wet tissue weight.

Number of Embryos Per Female Per Egg Laying Season in Relation to Female Wet Tissue Weight

The number of embryos egg case ${ }^{-1}$ was averaged for the number of egg cases counted from that individual female in the egg-laying season (year). The average number of embryos egg case $^{-1}$ was multiplied by the number of egg cases produced within one year by that particular individual female to give an estimate of the total number of embryos produced by an individual female ${ }^{-1}$ year ${ }^{-1}$ (i.e., fecundity). Estimated fecundity (number of embryos year ${ }^{-1}$ ) per female was plotted in relation to female wet tissue weight $(\mathrm{g})$.

\section{RESULTS}

During 2001 and 2003, the week in which the first rapa whelk in tanks at VIMS (either wild caught or cultured) was observed laying egg cases was designated week 1 of egg laying season and all subsequent weeks in which rapa whelks laid egg cases were assigned sequential ascending numbers. In 2001, egg laying began on May 14 (week 1, average water temperature of $18.0 \pm$ $0.14^{\circ} \mathrm{C}$, average salinity of $19.03 \pm 0.14 \mathrm{ppt}$ ) and ended on August 4 (week 12, water temperature of $25.9^{\circ} \mathrm{C} \pm 0.07^{\circ} \mathrm{C}$, average salinity of $19.52 \pm 0.09 \mathrm{ppt}$ ) for a duration of $11 \mathrm{wk}$. During the 2001 egg-laying season, the 14 wild caught female whelks laid a total of 22,581 egg cases. Of these, 235 were measured for egg case height (Ware 2002). Counts of numbers of embryos per egg cases for 153 of the egg cases measured were within the established parameters described above for within sample coefficients of variation. The 2003 egg laying season lasted 12 wk beginning on May 23 (week 1, average water temperature of $18.8^{\circ} \mathrm{C} \pm 0.19^{\circ} \mathrm{C}$, average salinity of $14.07 \pm 0.33$ ppt) and ending on August 28 (week 16, average water temperature of $26.9^{\circ} \mathrm{C} \pm 0.26^{\circ} \mathrm{C}$, average salinity of $12.78 \pm$ $0.27 \mathrm{ppt}$ ). The cultured whelks laid a total of 5,933 egg cases of which 160 were removed for measurement and enumeration of embryos. Counts of numbers of embryos per egg cases for 129 of the egg cases measured from cultured whelks were within the established parameters described earlier for within sample coefficients of variation.

\section{Female Shell Length Over Time}

Shell lengths of individual wild whelks did not change between May and August 2001 (ANOVA, $P=0.93$; Table 1). Shell lengths of individual wild whelks ranged from $73-163 \mathrm{~mm}$ with corresponding wet tissue weights recorded in August 2001 of $28-220 \mathrm{~g}$.

Average shell lengths of cultured whelks did not change significantly between May and August 2003 (culture specific ANOVAs, all $P$ values $>0.92$; Table 2 ). Shell lengths of individual whelks in group cultures ranged from $43.3-78.4 \mathrm{~mm}$ at the end of egg-laying season in August 2003.

\section{Female Wet Tissue Weight in Relation to Female Shell Length}

The relationship between whelk shell length $(\mathrm{mm})$ and wet tissue weight ( $\mathrm{g}$ ) for the size range of whelks used in these experiments was described using a power equation (Table 3, Fig. 1): 
TABLE 1.

Description of individual wild rapa whelk females that laid egg cases used in this study. Week of the egg laying season (WES) for first and last egg case production by each female is in relation to egg laying by all whelks under observation.

\begin{tabular}{|c|c|c|c|c|c|c|}
\hline $\begin{array}{l}\text { Whelk ID } \\
\text { Number }\end{array}$ & $\begin{array}{c}\text { Shell Length } \\
\text { May 2001 } \\
\text { (mm) }\end{array}$ & $\begin{array}{c}\text { Shell Length } \\
\text { Aug 2001 } \\
\text { (mm) }\end{array}$ & $\begin{array}{l}\text { Wet Tissue } \\
\text { Weight in } \\
\text { Aug } 2001 \text { (g) }\end{array}$ & $\begin{array}{c}\text { WES First } \\
\text { Egg Cases } \\
\text { Observed }\end{array}$ & $\begin{array}{c}\text { WES Last } \\
\text { Egg Cases } \\
\text { Observed }\end{array}$ & $\begin{array}{l}\text { Total Number of } \\
\text { Egg Cases Laid } \\
\text { May-Aug } 2001\end{array}$ \\
\hline 1 & 138 & 135 & 142 & 3 & 10 & 1,662 \\
\hline 2 & 127 & 128 & 102 & 3 & 12 & 1,949 \\
\hline 3 & 133 & 133 & 118 & 2 & 11 & 2,024 \\
\hline 4 & 152 & 152 & 218 & 1 & 11 & 1,324 \\
\hline 5 & 95 & 94 & 57 & 7 & 10 & 1,254 \\
\hline 6 & 149 & 152 & 200 & 2 & 11 & 1,647 \\
\hline 7 & 154 & 159 & 222 & 1 & 12 & 1,187 \\
\hline 8 & 134 & 133 & 132 & 2 & 12 & 2,074 \\
\hline 9 & 147 & 145 & 172 & 3 & 12 & 2,379 \\
\hline 10 & 158 & 163 & 220 & 4 & 12 & 1,823 \\
\hline 11 & 150 & 154 & 170 & 1 & 12 & 1,876 \\
\hline 12 & 74 & 73 & 28 & 3 & 11 & 437 \\
\hline 13 & 93 & 95 & 67 & 2 & 12 & 1,386 \\
\hline 14 & 136 & 143 & 151 & 3 & 8 & 1,559 \\
\hline
\end{tabular}

Wet tissue weight $=0.0002 \times$ shell length $^{2.6984}$;

$$
\mathrm{R}^{2}=0.99, n=56 \text { whelks. }
$$

\section{Number of Embryos Per Egg Case in Relation to Egg Case Height}

The relationship between the average number of embryos per egg case ( \pm SE of the mean) and egg case height $(\mathrm{mm})$ was described using a power equation (Table 3, Fig 2):

Average number of embryos per case

$$
\begin{aligned}
& =5.39 \times \text { Egg case } \text { height }^{1.71} ; \\
\mathrm{R}^{2} & =0.61, n=282 \text { egg cases. }
\end{aligned}
$$

\section{Egg Case Height in Relation to Female Wet Tissue Weight}

Female wet tissue weight (g) was related to egg case height $(\mathrm{mm})$ using the power equation (Table 3, Fig. 3):

$$
\begin{aligned}
\text { Egg case height } & =5.9041 \times \text { Female wet tissue weight }{ }^{0.305} ; \\
\mathrm{R}^{2} & =0.90, n=282 \text { egg cases. }
\end{aligned}
$$

The heights of egg cases produced by an individual may vary significantly within an egg-laying season (ANOVAs, Table 4). For four out of eight females egg cases laid early in the egglaying season were significantly taller than egg cases laid later in the season (ANOVAs, Table 4). Two of the eight females laid egg cases late in the season that were taller than egg cases laid early in the season (ANOVAs, Table 4).

\section{Number of Embryos Per Egg Case in Relation to Female Wet Tissue Weight}

Female wet tissue weight (g) was related to the number of embryos within an egg case using the power equation (Table 3 , Fig. 4):

TABLE 2.

Description of groups of cultured rapa whelks that laid egg cases used in this study. The number of females per group is the

\begin{tabular}{|c|c|c|c|c|c|c|}
\hline $\begin{array}{l}\text { Group ID } \\
\text { Number }\end{array}$ & $\begin{array}{l}\text { n Whelks/n } \\
\text { Females }\end{array}$ & $\begin{array}{c}\text { Average SL } \\
\text { (SEM) May } 2003\end{array}$ & $\begin{array}{c}\text { Average SL } \\
\text { (SEM) Aug } 2003\end{array}$ & $\begin{array}{l}\text { WES First Egg } \\
\text { Cases Observed }\end{array}$ & $\begin{array}{l}\text { WES Last Egg } \\
\text { Cases Observed }\end{array}$ & $\begin{array}{l}\text { Total Number of } \\
\text { Egg Cases Laid } \\
\text { May-Aug } 2003\end{array}$ \\
\hline 15 & $5 / 3$ & $68.4(2.06)$ & $68.2(2.04)$ & 8 & 15 & 844 \\
\hline 16 & $5 / 2$ & $66.3(2.82)$ & $66.3(2.84)$ & 9 & 16 & 754 \\
\hline 17 & $6 / 3$ & $75.4(3.52)$ & $75.2(3.18)$ & 4 & 13 & 2276 \\
\hline 18 & $3 / 1$ & 71.7 (2.66) & $71.3(3.23)$ & 11 & 16 & 517 \\
\hline 19 & $3 / 2$ & $74.6(3.15)$ & $74.4(3.27)$ & 7 & 16 & 1036 \\
\hline 20 & $2 / 1$ & $62.2(3.65)$ & $64.0(4.01)$ & 7 & 14 & 346 \\
\hline 21 & $3 / 1$ & $66.7(1.23)$ & $66.7(1.31)$ & 11 & 16 & 131 \\
\hline 22 & $5 / 2$ & $55.2(1.51)$ & $56.3(1.95)$ & 5 & 13 & 508 \\
\hline 23 & $4 / 1$ & $44.4(1.85)$ & $45.1(1.79)$ & 32 & 32 & 23 \\
\hline
\end{tabular}
maximum number of individuals within a culture observed laying different egg masses at the same time on at least three different occasions during 2002 and 2003. Average shell lengths (SL) with standard error of the mean (SEM) values are presented for May (before egg laying) and August (after egg laying) 2003. The week of the egg-laying season (WES) in which the first and last observations of egg case deposition were made are indicated for each culture. 
TABLE 3.

Summary of regression models and coefficients used to describe rapa whelk fecundity in relation to female size. Relationships are for (A) shell length:wet tissue weight, (B) egg case height:number of embryos egg case ${ }^{-1}$, (C) wet tissue weight: egg case height, (D) wet tissue weight:number of embryos case ${ }^{-1},(E)$ wet tissue weight:number of egg cases egg laying season $\left(=\right.$ year $^{-1}$, $\left(F_{A}\right)$ wet tissue weight: average number of embryos female year $^{-1}$.

\begin{tabular}{|c|c|c|c|c|c|c|c|}
\hline Relationship & $\begin{array}{c}\text { Regression } \\
\text { Model }\end{array}$ & $\mathbf{R}^{2}$ Value & $\begin{array}{c}\text { Model } \\
\text { Coefficents }\end{array}$ & $\begin{array}{l}\text { Std Error of } \\
\text { Coefficients }\end{array}$ & $\begin{array}{c}p \text { Value } \\
\text { Coefficent }\end{array}$ & $\begin{array}{c}\text { F Value } \\
\text { Regression }\end{array}$ & $\begin{array}{c}p \text { Value } \\
\text { Regression }\end{array}$ \\
\hline \multirow[t]{2}{*}{ A } & \multirow[t]{2}{*}{ Power } & \multirow[t]{2}{*}{0.99} & $\mathrm{a}=0.0002$ & 0.0001 & $<0.02$ & \multirow[t]{2}{*}{4774.36} & \multirow[t]{2}{*}{$<0.01$} \\
\hline & & & $\mathrm{b}=2.6984$ & 0.08 & $<0.01$ & & \\
\hline \multirow[t]{2}{*}{ B } & \multirow[t]{2}{*}{ Power } & \multirow[t]{2}{*}{0.61} & $\mathrm{a}=5.39$ & 1.68 & $<0.01$ & \multirow[t]{2}{*}{426.67} & \multirow[t]{2}{*}{$<0.01$} \\
\hline & & & $\mathrm{b}=1.71$ & 0.01 & $<0.01$ & & \\
\hline \multirow[t]{2}{*}{$\mathrm{C}$} & \multirow[t]{2}{*}{ Power } & \multirow[t]{2}{*}{0.90} & $\mathrm{a}=5.9041$ & 0.16 & $<0.01$ & \multirow[t]{2}{*}{2627.5} & \multirow[t]{2}{*}{$<0.01$} \\
\hline & & & $\mathrm{b}=0.305$ & 0.01 & $<0.01$ & & \\
\hline \multirow[t]{2}{*}{$\mathrm{D}$} & \multirow[t]{2}{*}{ Power } & \multirow[t]{2}{*}{0.61} & $\mathrm{a}=91.7498$ & 14.34 & $<0.01$ & \multirow[t]{2}{*}{448.47} & \multirow[t]{2}{*}{$<0.01$} \\
\hline & & & $\mathrm{b}=0.5670$ & 0.03 & $<0.01$ & & \\
\hline \multirow[t]{2}{*}{$\mathrm{E}$} & \multirow[t]{2}{*}{ Power } & \multirow[t]{2}{*}{0.67} & $\mathrm{a}=161.1$ & 71.31 & 0.03 & \multirow[t]{2}{*}{43.39} & \multirow[t]{2}{*}{$<0.01$} \\
\hline & & & $\mathrm{b}=0.4622$ & 0.09 & $<0.01$ & & \\
\hline \multirow[t]{2}{*}{$\mathrm{F}_{\mathrm{A}}$} & \multirow[t]{2}{*}{ Power } & \multirow[t]{2}{*}{0.62} & $\mathrm{a}=43,359.12$ & $54,849.61$ & 0.44 & \multirow[t]{2}{*}{24.98} & \multirow[t]{2}{*}{$<0.01$} \\
\hline & & & $\mathrm{b}=0.7820$ & 0.2472 & 0.01 & & \\
\hline
\end{tabular}

Number of embryos per egg case

$$
\begin{aligned}
& =91.75 \times \text { Female wet tissue weight }{ }^{0.5670} ; \\
\mathrm{R}^{2} & =0.61, n=282 \mathrm{egg} \text { cases. }
\end{aligned}
$$

Four of the eight females put significantly more embryos in the egg cases laid early in the egg-laying season than in egg cases laid late in the egg-laying season (ANOVAs, Table 5). The smallest two females that packaged more embryos per egg case earlier in the season than later also laid taller egg cases earlier in the season than later in the season (Tables 4 and 5).

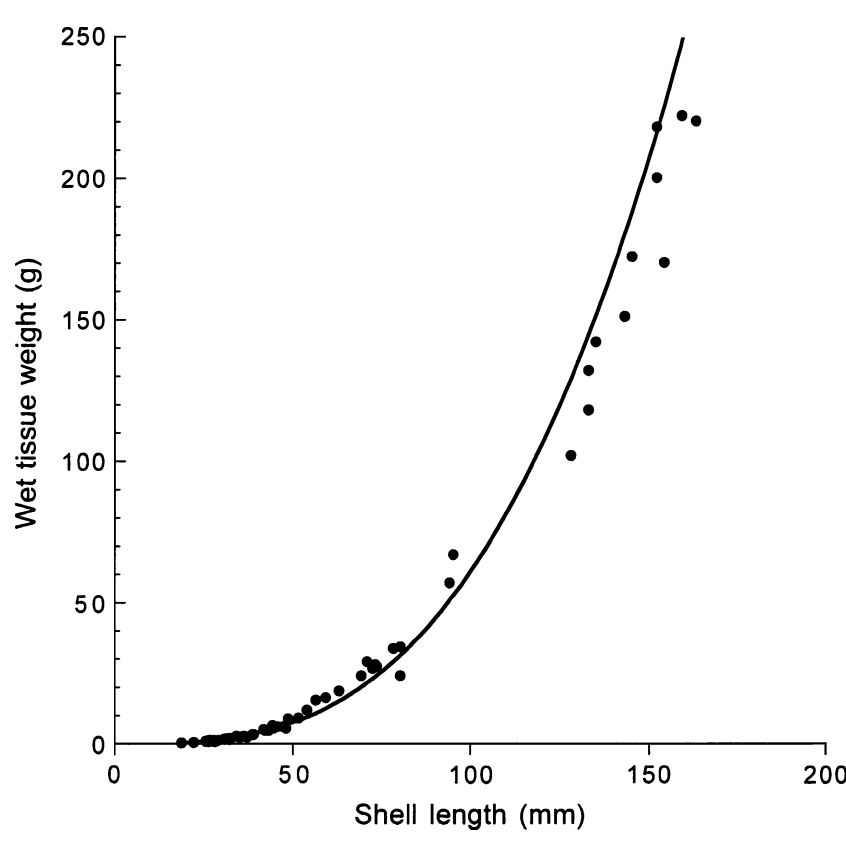

Figure 1. Plot of shell length ( $\mathrm{mm}$ ) and wet tissue wet (g) for 56 individual rapa whelks. The fitted power relationship is: wet tissue weight $=0.0002 \times$ Shell length ${ }^{2.6984} ; \mathbf{R}^{2}=0.99$.
Number of Egg Cases Laid by an Individual During One Egg Laying Season in Relation to Female Wet Tissue Weight

The total number of egg cases produced by a female whelk in one egg-laying season (year) was described in relation to female wet tissue weight (g) using a power equation (Table 3, Fig. 5):

Number of egg cases female ${ }^{-1}$

$$
\begin{aligned}
& =161.1 \times \text { Female wet tissue weight }{ }^{0.4622} ; \\
\mathrm{R}^{2} & =0.67, n=23 \text { female rapa whelks. }
\end{aligned}
$$

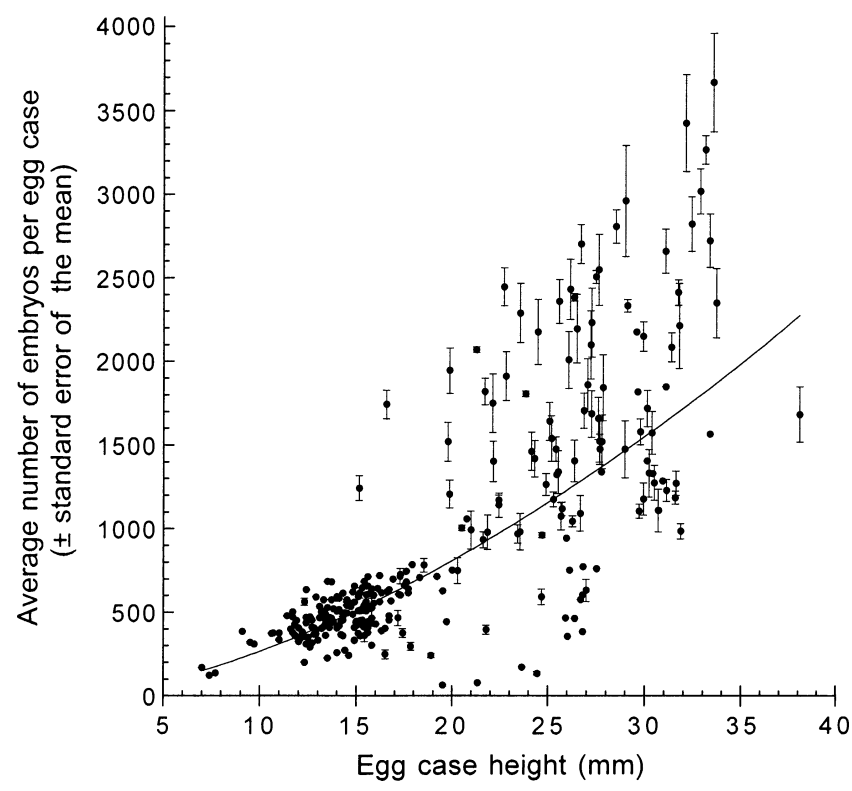

Figure 2. Rapa whelk egg case height $(\mathrm{mm})$ in relation to the average number of embryos in each egg case ( $\pm \mathrm{SE}$ of the mean). Data from $282 \mathrm{egg}$ cases laid by whelks $45-163-\mathrm{mm}$ SL are presented. The regression equation for the fitted power relationship is: average number of embryos egg case $^{-1}=5.39 \times$ Egg case height ${ }^{1.71} ; R^{2}=0.61$. 


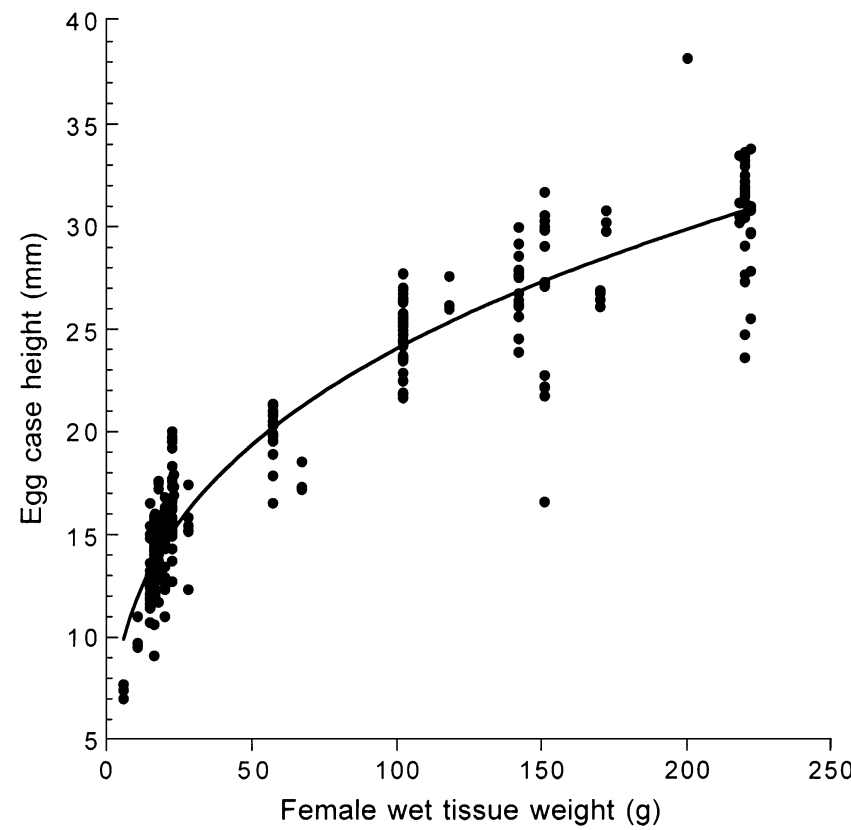

Figure 3. Female wet tissue weight $(\mathrm{g})$ in relation to egg case height $(\mathbf{m m})$ of egg cases produced by that individual ( $n=282$ egg cases). The fitted power relationship is: egg case height $=5.9041 \times$ female wet tissue weight $^{0.305} ; \mathbf{R}^{2}=0.90$.

\section{Number of Embryos Per Egg Laying Season Per Female in Relation to Female Wet Tissue Weight}

The average number of embryos in all egg cases produced by one female in one year (average fecundity) was related to female wet tissue weight with a power equation (Table 3, Fig. 6):

Average fecundity $=43,359.12 \times$ Female wet tissue weight $^{0.7820}$;

$$
\mathrm{R}^{2}=0.62 ; n=17 \text { female rapa whelks. }
$$

Data sources for this relationship were limited to female whelks that produced egg cases in which three or more counts of embryos case $^{-1}$ resulted in coefficients of variation less than $2 \%$ (total $\mathrm{n}$ of 17 females for this relationship).

\section{DISCUSSION}

Rapa whelk fecundity (number of embryos female ${ }^{-1} \mathrm{yr}^{-1}$ ) increases with female size and weight. Egg case production was observed in rapa whelks as small as $45 \mathrm{~mm} \mathrm{SL}$ (wet tissue weight of $5.8 \mathrm{~g}$ ) that had hatched or been released from egg masses 11 mo previously. Small ( $<80 \mathrm{~mm} \mathrm{SL},<28 \mathrm{~g}$ wet tissue weight) rapa whelks have relatively lower annual fecundities $\left(1 \times 10^{5}\right.$ embryos female $\left.\mathrm{yr}^{-1}\right)$ than large $(>80 \mathrm{~mm} \mathrm{SL},>28 \mathrm{~g}$ wet tissue weight) whelks that may produce between $1 \times 10^{6}$ and $4 \times 10^{6}$ embryos female ${ }^{-1} \mathrm{yr}^{-1}$. Annual fecundity is related to a combination of factors including egg case dimensions, number of embryos case ${ }^{-1}$, the number of egg cases produced female ${ }^{-1}$ year $^{-1}$ and the duration of the egg laying season within a year.

Egg case height and the number of embryos per egg case are positively correlated with female size. The smallest Chesapeake Bay rapa whelks observed in this study $(45 \mathrm{~mm}$ SL, $5.8 \mathrm{~g}$ wet tissue weight) laid egg cases with heights of approximately $7 \mathrm{~mm}$, whereas the largest whelk (163 mm SL, $220 \mathrm{~g})$ laid egg
TABLE 4.

Summary of ANOVAs used to evaluate egg case height $(\mathrm{mm})$ in relation to week of the egg-laying season (factor $=$ week, response $=$ egg case height) for individual rapa whelks and groups of cultured whelks for which there was only 1 known female. For both individuals and groups, more than two egg cases were measured for at least two separate weeks during the egg-laying season. Asterisks indicate results that were significant at the $\boldsymbol{P}=\mathbf{0 . 0 5}$ level.

\begin{tabular}{crrcl}
\hline \hline $\begin{array}{c}\text { Animal or } \\
\text { Culture ID }\end{array}$ & df & F Value & $\boldsymbol{p}$ Value & $\begin{array}{c}\text { Fisher Multiple Comparison } \\
\text { Test Results }\end{array}$ \\
\hline 1 & 3 & 0.55 & 0.66 & \\
2 & 5 & 5.14 & $<0.01^{*}$ & weeks 4, 8 taller than week 9 \\
5 & 2 & 18.83 & $<0.01^{*}$ & weeks 8,10 taller than week 7 \\
10 & 4 & 2.16 & 1.27 & \\
15 & 2 & 6.37 & $0.02^{*}$ & week 3 taller than week 4 \\
18 & 4 & 3.65 & $0.03^{*}$ & week 15, 16 taller than week 13 \\
20 & 4 & 14.46 & $<0.01^{*}$ & $\begin{array}{c}\text { week 7 taller than } \\
\text { weeks 11, 12, 13, 14 } \\
\end{array}$ \\
21 & 2 & 9.27 & $<0.01^{*}$ & weeks 11, 13 taller than week 16 \\
\hline
\end{tabular}

cases with heights $30-33 \mathrm{~mm}$. The number of embryos observed in egg cases produced by Chesapeake Bay rapa whelks ranged from 123 (7.4 mm high egg case) to 3,673 (33.5 mm high egg case). Chung et al. (1993) describe egg cases with heights of 25$27 \mathrm{~mm}$ containing an average of 1,096 embryos per case laid by Korean rapa whelks 120-140 mm shell length. D'Asaro (1991) describes "larger" egg cases of $R$. venosa from southern Japan as 31-36 mm in height. Amio (1963) describes egg capsules from Japan $30 \mathrm{~mm}$ high containing 790-1,300 embryos per case. Chukhchin (1984) collected rapa whelk egg cases with heights ranging from 6-24 mm containing 200-1,000 embryos per case in the Black Sea from parents of unknown size. Based on these

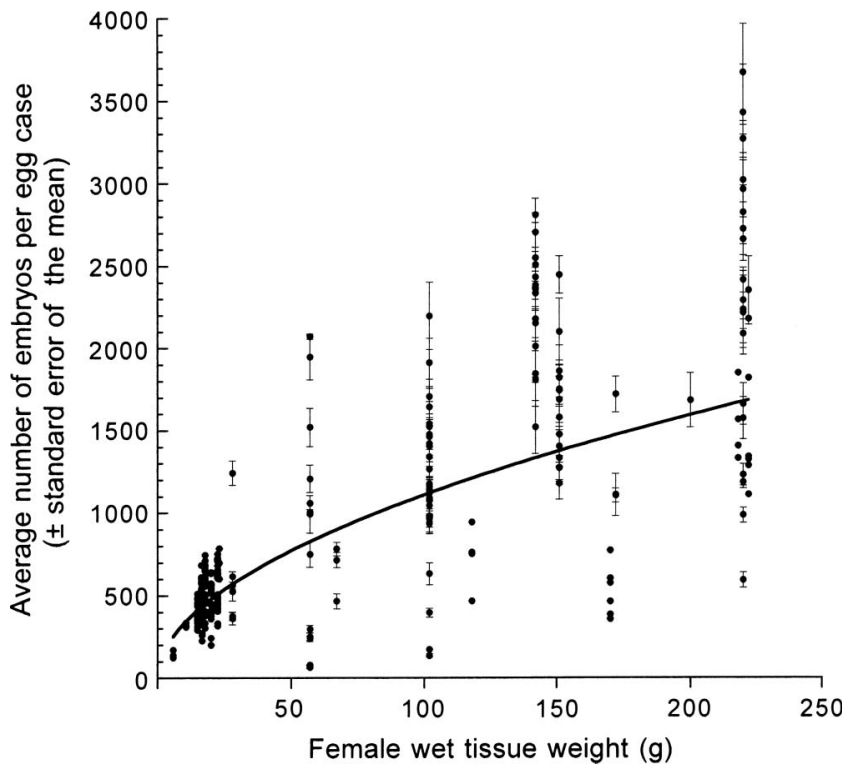

Figure 4. Female wet tissue weight (g) in relation to the average number of embryos ( $\triangle \mathrm{SE}$ of the mean) in each egg case produced by that individual ( $n=282$ egg cases enumerated). The fitted power relationship is: number of embryos egg case $^{-1}=91.75 \times$ Female wet tissue weight $^{0.5670} ; R^{2}=0.61$. 
TABLE 5.

Summary of ANOVAs used to describe number of embryos per egg case in relation to week of the egg laying season (factor = week, response $=$ number of embryos per egg case) for individual rapa whelks and groups of cultured rapa whelks for which there was only 1 known female. For both individuals and groups, more than two egg cases were analyzed for at least two separate weeks during the egg-laying season.

\begin{tabular}{|c|c|c|c|c|}
\hline $\begin{array}{l}\text { Animal or } \\
\text { Culture ID }\end{array}$ & df & F Value & $p$ Value & $\begin{array}{c}\text { Fisher Multiple } \\
\text { Comparison Test Results }\end{array}$ \\
\hline 1 & 3 & 2.64 & 0.12 & \\
\hline 2 & 5 & 1.50 & 0.23 & \\
\hline 5 & 2 & 0.94 & 0.43 & \\
\hline 10 & 4 & 6.08 & $0.01 *$ & $\begin{array}{l}\text { More embryos per case } \\
\text { in week } 4^{1} \text { than either } \\
\text { week } 9 \text { or week } 12\end{array}$ \\
\hline 15 & 2 & 1.92 & 2.02 & \\
\hline 18 & 4 & 5.15 & $0.01^{*}$ & $\begin{array}{l}\text { More embryos per case } \\
\text { in week } 11^{1} \text { than } \\
\text { week } 12\end{array}$ \\
\hline 20 & 4 & 3.29 & $0.04^{*}$ & $\begin{array}{l}\text { More embryos per case } \\
\text { in week } 7^{1} \text { than } \\
\text { weeks } 11 \text { or } 12\end{array}$ \\
\hline 21 & 2 & 9.38 & $0.01 *$ & $\begin{array}{l}\text { More embryos per case } \\
\text { in weeks } 11^{1} \text { and } 14 \\
\text { than week } 16\end{array}$ \\
\hline
\end{tabular}

${ }^{1}$ Week of first egg laying within the egg-laying season for this whelk.

* Indicate results that were significant at the $P=0.05$ level.

observations, Chesapeake Bay rapa whelk females appear to produce egg cases of comparable size to those produced by rapa whelks in their native range (Japan and Korea), whereas Black Sea rapa whelks seem to produce egg cases that are smaller than those from either Asia or Chesapeake Bay.

When there was variation in the number of embryos case ${ }^{-1}$, the first egg masses in the egg-laying season had more embryos case $^{-1}$ than egg cases produced later in the season. This pattern was observed in some of the smallest whelks (64-71.3 mm SL; $18-26 \mathrm{~g}$ wet tissue weight) as well as the largest whelk (163 mm $\mathrm{SL}, 220 \mathrm{~g}$ wet tissue weight). There may be an adaptive advantage in producing more embryos early in the season for both larval survival to settlement and larval growth post settlement. Under culture conditions, rapa whelks that settle by August 15, often attain sizes $>25 \mathrm{~mm}$ SL before water temperatures fall below $10^{\circ} \mathrm{C}$ in October to November, and these juvenile whelks are also reproductively active the summer after they hatch and settle (Harding, unpublished data). For rapa whelks in wild habitats, attainment of relatively large sizes postsettlement prior to the first winter may translate into reduced generation time, increased propagule pressure, the rate at which breeding individuals are released by adults (Williamson 1996), in the habitat and attainment of a size refuge from predation ahead of conspecifics (Harding 2003).

Although there is a consistent trend in that larger rapa whelks produced larger egg cases, a single female may lay egg cases that differ significantly in height within an egg-laying season. Ramesh (1999) observed the presence of both small and large egg cases within the same egg mass more commonly at the end of the egg-laying season for the Turnip whelk, Rapana rapiformis. In our study, larger rapa whelks usually produced

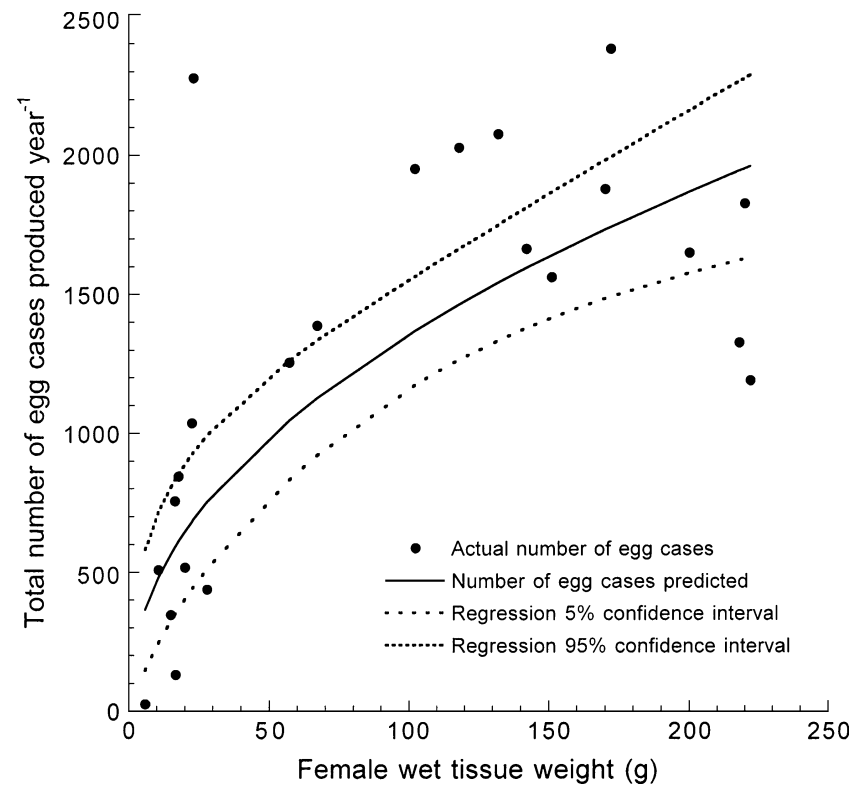

Figure 5. Female wet tissue weight $(\mathrm{g})$ in relation to the total number of egg cases produced by that individual in one year or egg laying season. The fitted power regression, shown with upper and lower $95 \%$ confidence limits, is: number of egg cases female ${ }^{-1}=161.1 \times$ Female wet tissue weight $^{0.4622} ; \mathrm{R}^{2}=0.67$.

larger egg cases, but a single female may lay egg cases that differ significantly in height within an egg-laying season. In addition, the number of eggs within the case varied with the time of egg case deposition.

Two of the eight individuals that displayed intra-annual variation in egg case height also displayed within-season

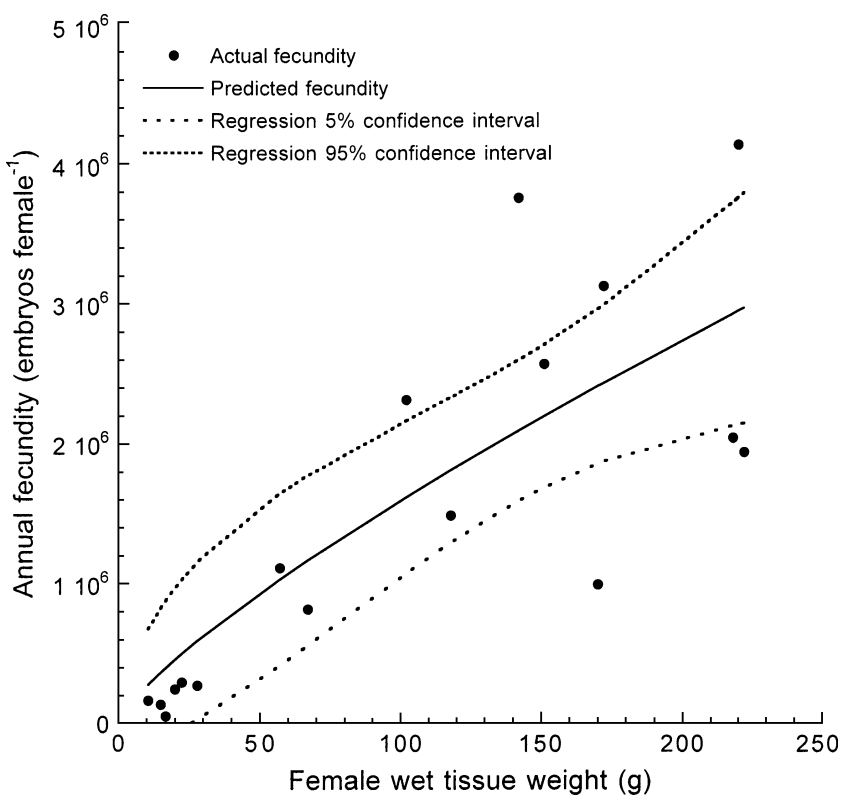

Figure 6. Female wet tissue weight $(\mathrm{g})$ in relation to the average number of embryos ( $\pm \mathrm{SE}$ of the mean) produced by that individual in one year or egg laying season (i.e., annual fecundity). The fitted power regression, shown with upper and lower $95 \%$ confidence limits, is: average fecundity = 43,359.12 $\times$ Female wet tissue weight ${ }^{0.7820} ; \mathbf{R}^{2}=0.62$. 
variability in the number of embryos per egg case. During the same weeks that these individuals laid larger egg cases, the egg cases that were deposited contained more embryos. The observed variation in egg case height may be an adaptive pattern to produce embryos at a particular time during the egg-laying season and perhaps enhance larval survival to settlement and growth post settlement. Alternatively, differences in egg case height may be a visible manifestation of parental condition at a particular time. Although food was not a limiting factor in this study, rapa whelks were never observed feeding during egg case deposition. If a female lays several consecutive egg masses between feeding events, it is possible that she may have fewer energy resources available for egg capsule and embryo production for the last egg mass(es) in the sequence.

The number of egg cases produced by one female in one egglaying season is also related to parent size. Large whelks (>80 mm SL, >38 g wet tissue weight) begin laying egg masses before smaller whelks ( $<80 \mathrm{~mm} \mathrm{SL},<37.9$ g wet tissue weight), and the duration of egg-laying season was an average of $2 \mathrm{wk}$ longer for large whelks than small whelks. Small whelks lay between 100 and 1,000 egg cases per season, whereas large whelks may lay more than 1,000 egg cases year ${ }^{-1}$ with as many as 2,379 egg cases female ${ }^{-1}$ observed in 2001. Egg case production at these levels translates into annual fecundity (i.e., embryos female ${ }^{-1}$ year $^{-1}$, estimates on the order of $1 \times 10^{5}$ for smaller whelks and in excess of $1 \times 10^{6}$ for larger rapa whelks).

At the population level, propagule pressure is related to individual fecundity, generation time, adult size, and life span. Rapa whelks have generation times of $1 \mathrm{y}$, large adult size (>160 mm SL), a positive relationship between fecundity and female size, and may live in excess of $15 \mathrm{y}$. Thus rapa whelk life history strategy incorporates traits, which elevate propagule pressure. This life history strategy is in stark contrast to the life history strategies used by most other temperate gastropods native to the United States Atlantic coast (Table 6). Other gastropod predators in the Chesapeake Bay, including the Atlantic oyster drill Urosalpinx cinerea and the thick-lipped oyster drill Eupleura caudata as well as knobbed whelks Busycon carica, rely on direct development of their young (Table 6). Although Urosalpinx and Eupleura reach sexual maturity in 1$2 \mathrm{y}$, they are shorter lived and much smaller than rapa whelks (adult sizes 20-40 mm SL). Knobbed whelks require 7-9 y to reach sexual maturity (Castagna \& Kraeuter 1994) although they are similar in size compared to large adult rapa whelks. Like Rapana, the Southern oyster drill Stramonita haemastoma relies on planktonic larval development and in many ways Stramonita life history is parallel to that of Rapana. The success of $S$. haemastoma as an apex shellfish predator in temperate United States estuaries has long been recognized (Burkenroad 1931, Butler 1954, Gunter 1985).

Rapa whelk reproductive potential is greater than that of the Southern oyster drill because of the rapa whelk's larger adult size and longer life expectancy (Table 6). On an annual basis, estimates of rapa whelk fecundity are at least an order of magnitude higher than similar estimates for native gastropods (Table 6). When extended over a life span of more than $15 \mathrm{y}$, the differences in potential fecundity between rapa whelks and native gastropods are very large.

The rapa whelk's status as an invasive species is unusual given its large adult size. Traditionally, invasive gastropods have been small, and adults were transported across zoogeographic boundaries and introduced to new habitats in association with rocks used for ship's ballast, attached to ship's hulls

TABLE 6.

Summary of life history features of selected temperate gastropods from the United States Atlantic coast.

\begin{tabular}{|c|c|c|c|c|c|}
\hline & Urosalpinx cinerea ${ }^{1}$ & Eupleura caudata ${ }^{2}$ & $\begin{array}{c}\text { Stramonita }(=\text { Thais }) \\
\text { haemastoma }^{3}\end{array}$ & Rapana venosa $a^{4}$ & Busycon carica ${ }^{5}$ \\
\hline Family & Muricidae & Muricidae & Muricidae & Muricidae & Melongenidae \\
\hline Native range & $\begin{array}{r}\text { Nova Scotia } \\
\text { to Florida }\end{array}$ & $\begin{array}{l}\text { Massachusetts } \\
\text { to Florida }\end{array}$ & $\begin{array}{c}\text { Cape Hatteras } \\
\text { to Texas }\end{array}$ & $\begin{array}{l}\text { Yellow Sea, } \\
\text { East China Sea, } \\
\text { Sea of Japan }\end{array}$ & $\begin{array}{c}\text { Massachusetts } \\
\text { to Florida }\end{array}$ \\
\hline Status on US East coast & Native & Native & Native & $\begin{array}{l}\text { Introduced to } \\
\text { Chesapeake Bay }\end{array}$ & Native \\
\hline Maximum adult shell length & $35 \mathrm{~mm}$ & $45 \mathrm{~mm}$ & $75 \mathrm{~mm}$ & $180 \mathrm{~mm}$ & $230 \mathrm{~mm}$ \\
\hline Life span & $3-5 y$ & $3-5 y$ & $5-10 y$ & $>15 \mathrm{y}$ & $>15 \mathrm{y}$ \\
\hline Age at maturity & $1-3 y$ & $2-3 y$ & $1 \mathrm{y}$ & $1 \mathrm{y}$ & $7-9 y$ \\
\hline Method of larval development & Direct & Direct & Planktonic & Planktonic & Direct \\
\hline \multicolumn{6}{|l|}{ Temperature range for egg } \\
\hline case deposition & $18-26^{\circ} \mathrm{C}$ & $>18^{\circ} \mathrm{C}$ & $20-30^{\circ} \mathrm{C}$ & $>18^{\circ} \mathrm{C}$ & $>18^{\circ} \mathrm{C}$ \\
\hline Number of egg masses per year & $>1$ & $1-18$ & $>1$ & $2-18$ & $>1$ \\
\hline Number of egg cases per mass & $4-22$ & $2-15$ & $5-150$ & $4-599$ & $42-121$ \\
\hline Number of embryos per egg case & $8-10$ & $12-21$ & $3-4,000$ & $113-3,258$ & $30-51$ \\
\hline $\begin{array}{l}\text { Estimated fecundity } \\
\qquad\left(\text { embryos female }^{-1} \mathrm{yr}^{-1}\right)\end{array}$ & $4 \times 10^{2}$ & $1 \times 10^{3}$ & $>5 \times 10^{5}$ & $>1 \times 10^{6}$ & $2-3 \times 10^{3}$ \\
\hline
\end{tabular}

${ }^{1}$ Urosalpinx cinerea information is from Federighi (1931), Carriker (1954, 1955), and Franz (1971).

2 Eupleura caudata information is from Carriker (1955) and MacKenzie (1961).

3 Stramonita haemastoma information is from Burkenroad (1931), Butler (1954), D'Asaro (1966), and Roller and Stickle (1988, 1989).

${ }^{4}$ Rapana venosa information is from Ware (2002), Mann et al. (2004), Harding (2006) and the present study.

${ }^{5}$ Busycon carica information is from Maghalaes (1948) and Castagna and Kraeuter (1994). 
as part of the fouling community or as part of the fouling community on desired aquaculture species (Carlton 1999). In the 20th century, ballast water has supplanted fouled bottoms and rock ballast as the major vector for species transport between aquatic habitats. This transition favors species that have pelagic larvae over smaller species that live cryptically on hard surfaces (hulls or sea chests) or those that lay egg capsules with extended development that are surface attached. Modern shipping traffic, the current dominant transport vector for aquatic species, provides a means to overcome natural zoogeographic boundaries on temporal scales that are less than the planktonic larval period for many species. The transport of veliger larvae in ballast water is a 20th century phenomenon that developed with the advent of large commercial ships. To be considered a success in a novel habitat, an invasive species must survive long enough to reproduce and maintain sufficient propagule pressure to produce a viable population of adults (Willamson 1996).

Species with reproductive strategies that maximize reproductive output over a short generation time are more likely to be successful in a novel environment than species, which require longer generation times and/or have lower fecundities (Sakai et al. 2001). Rapa whelk life history and reproductive strategies, which combine elements of both $r$ and $K$ selection enable this gastropod to opportunistically exploit habitat niches that may be vacant or under used in receptor habitats and successfully compete with native species that share habitat requirements. The rapa whelk's life history pattern includes generation times of $1 \mathrm{y}$, large adult size (>160 mm SL), a positive relationship between fecundity and female size, life spans in excess of a decade and the ability to produce large numbers of planktonic larvae at all ages. The combination of this life history with generalist food requirements and broad environmental tolerances is central to the success of this large gastropod as an invasive species (Sakai et al. 2001). Given the continued anthropogenic transport of planktonic larvae between intercoastal habitats, the advantages of these traits as demonstrated by rapa whelks and other invasive species in colonizing new habitats will continue to be examined as replicates of the same experiment across latitudinal and zoogeographic gradients.

\section{ACKNOWLEDGMENTS}

The author thanks all of the local citizens, watermen, and seafood processors that have donated adult Rapana to our research program. A. Bohannon, R. Howlett, E. Jestel, R. Johnson, D. Kerstetter, P. Kingsley-Smith, and M. Southworth assisted with local whelk collection. M. Fagan and T. Drummond assisted with laboratory processing and enumeration of rapa whelk embryos. Support for this project was provided by the NOAA/National Sea Grant Aquatic Nuisance Species Research and Outreach Program (NA96RG0025/ 5-29456), Virginia Sea Grant (R/MG-98-3), and the Virginia Institute of Marine Science Department of Fisheries Science. This is Contribution number 2805 from the Virginia Institute of Marine Science.

\section{LITERATURE CITED}

Amio, M. 1963. A comparative embryology of marine gastropods with ecological considerations. J. of Shimonoseki University of Fisheries 12:15-143.

Burkenroad, M. 1931. Notes on the Louisiana conch, Thais haemastoma, Linn., in its relation to the oyster Ostrea virginica. Ecology 12:656-664.

Butler, P. 1954. The southern oyster drill. Proc. Natn. Shellfish. Ass. 44:67-75.

Carlton, J. 1999. Molluscan invasions in marine and estuarine communities. Malacalogia. 41:439-454.

Carriker, M. 1954. Seasonal vertical movements of oyster drills. Proc. Natn. Shellfish. Ass. 45:190-198.

Carriker, M. 1955. Critical review of biology and control of oyster drills Urosalpinx and Eupleura. US Dept of the Interior Fish and Wildlife Service Special Scientific Report Fisheries No. 148. $150 \mathrm{pp}$.

Castagna, M. \& J. Kraeuter. 1994. Age, growth rate, sexual dimorphism and fecundity of knobbed whelk Buyscon carica (Gmelin, 1791) in a western mid-Atlantic lagoon system, Virginia. J. Shellfish Res. 13:581-585.

Chukhchin, V. 1984. Ecology of gastropoda from the Black Sea. Naukova Dumka. Kiev. (In Russian). 176 pp.

Chung, E. Y., S. Y. Kim \& Y. G. Kim. 1993. Reproductive ecology of the purple shell, Rapana venosa (Gastropod: Muricidae), with special reference to the reproductive cycle, deposition of egg capsules and hatching of larvae. Korean J. Malacol. 9:1-15.

D'Asaro, C. 1966. The egg capsules, embryogenesis, and early organogenesis of a common oyster predator, Thais haemastoma floridana (Gastropoda: Prosobranchia). Bull. Mar. Sci. 16:884-914.

D'Asaro, C. 1991. Gunnar Thorson's worldwide collection of prosobranch egg capsules: Muricidae. Ophelia. 35:1-101.
Drapkin, E. 1963. Effect of Rapana bezoar Linne' (Mollusca: Muridicae) on the Black Sea fauna. Doklady Akademii Nauk SRR. 151:700-703.

Federighi, H. 1931. Studies on the oyster drill (Urosalpinx cinerea, Say). Bull. U.S. Bur. Fish. 47:83-115.

Franz, D. 1971. Population age structure, growth, and longevity of the marine gastropod Urosalpinx cinerea Say. Biol. Bull. 140:63-72.

Gunter, G. 1985. Synoptic review of the literature on the Southern Oyster Drill Thais haemastoma floridana. NOAA Technical Report NMFS 35.12 pp.

Harding, J. M. 2003. Blue crabs Callinectes sapidus as a potential control mechanism for a non-native predatory gastropod, Rapana venosa. J. Exp. Mar. Biol. Ecol. 297:161-177.

Harding, J. M. 2006. Growth and development of veined rapa whelk Rapana venosa veligers. J. Shellfish Res. 25:941-946.

Harding, J. M. \& R. Mann. 1999. Observations on the biology of the Veined Rapa whelk, Rapana venosa (Valenciennes, 1846) in the Chesapeake Bay. J. Shellfish Res. 18:9-18.

Harding, J. M. \& R. Mann. 2005. Veined rapa whelk Rapana venosa range extensions in Virginia waters of Chesapeake Bay, U.S.A. J. Shellfish Res. 24:381-385.

Ilano, A. S., K. Fujinaga \& S. Nakao. 2004. 2004. Mating, development, and effects of female size on offspring number and size in the Neogastropod Buccinum isaotakii (Kira, 1959). J. Molluscan Stud. 70:277-282.

MacKenzie, C. 1961. Growth and reproduction of the oyster drill Eupleura caudata in the York River, Virginia. Ecology 42:317338.

Magalhaes, H. 1948. An ecological study of the snails of the genus Busycon at Beaufort, North Carolina. Ecol. Monogr. 18:377-409.

Mann, R. \& J. M. Harding. 2000. Invasion of a Mid Atlantic estuary by the oriental gastropod Rapana venosa Valenciennes, 1846. Biol. Invasions 2:7-22. 
Mann, R. \& J. M. Harding. 2003. Salinity tolerances of larval Rapana venosa: implications for dispersal and establishment of an invading predatory gastropod on the North American Atlantic coast. Biol. Bull. 204:96-103.

Mann, R., A. Occhipinti \& J. M. Harding. 2004. Current status of global invasions by the marine gastropod Rapana venosa. First special report of the International Council for Exploration of the Seas on the status of introduced species. International Council for Exploration of the Seas/ICES. 24th Annual meeting of ICES (WGITMO), Goteborg, Sweden, March 20-21, 2002.

Mohlenberg, F. 1987. A submersible net pump for quantitative sampling, comparison with conventional net sampling. Ophelia 27:101-110.

Pastorino, G., P. Penchaszadeh, L. Schejter \& C. Bremec. 2000. Rapana venosa (Valenciennes, 1846) (Mollusca: Muricidae): a new gastropod in south Atlantic waters. J. Shellfish Res. 19:897-899.

Pechenik, J. 1986. The encapsulation of eggs and embryos by molluscs: an overview. Am. Malacol. Bull. 4:165-172.

Ramesh, R. 1999. Spawning and larval development of Rapana rapiformis (Born) (Mollusca: Gastropoda). Phuket Marine Biological Center Special Publication No. 19. pp.113-117.

Roller, R. \& W. Stickle. 1988. Intracapsular development of Thais haemastoma canaliculata (Gray) (Prosobranchia: Muricidae) under laboratory conditions. Am. Malacol. Bull. 6:189-197.

Roller, R. \& W. Stickle. 1989. Temperature and salinity effects on the intracapsular development, metabolic rates, and survival to hatch- ing of Thais hameastoma canaliculata (Gray) (Prosobranchia: Muricidae) under laboratory conditions. J. Exp. Mar. Biol. Ecol. 125:235-251.

Sakai, A., F. Allendorf, J. Holt, D. Lodge, J. Molofsky, K. With, S. Baughman, R. Cabin, J. Cohen, N. Ellstrand, D. McCauley, P. O’Neil, I. Parker, J. Thompson \& S. Weller. 2001. The population biology of invasive species. Annu. Rev. Ecol. Syst. 32:305-332.

Spight, T., C. Birkeland \& A. Lyons. 1974. Life histories of large and small murexes (Prosobranchia: Muricidae). Mar. Biol. 24:229242 .

Spight, T. \& J. Emlen. 1976. Clutch sizes of two marine snails with a changing food supply. Ecology 57:1162-1178.

Van Guelpen, L., D. F. Markle \& D. J. Duggan. 1982. An evaluation of accuracy, precision, and speed of several zooplankton subsampling techniques. J. Const. Int. Explor. Mer. 40:226-236.

Vink, R. D. Nieweg \& H. Post. 2005. Rapana venosa (Valenciennes, 1846): a new invasive species for the Netherlands (and England?). (In Dutch with English abstract). Spirula 345:152-155.

Ware, C. 2002. Temporal and spatial variation in reproductive output of the veined rapa whelk (Rapana venosa) in the Chesapeake Bay. M.S. thesis. College of William and Mary, Williamsburg, Virginia. 76 pp.

Williamson, M. 1996. Biological invasions. New York: Chapmann and Hall. 244 pp.

Zar, J. 1996. Biostatistical Analysis, 3rd ed. Saddle River: Prentice Hall. $662 \mathrm{pp}$. 